\title{
The Role of Digital Innovation and Its Impact on Competitiveness and Performance: The Case of Business Hotel in Indonesia
}

\author{
Ananta Budhi DANURDARA ${ }^{{ }^{*}}$, Haryadi DARMAWAN ${ }^{2}$, ER. Ummi KALSUM ${ }^{3}$ \\ ${ }^{1}$ Lecturer at Sekolah Tinggi Pariwisata Bandung, Jl. Dr. Setiabudhi No.186, Bandung Indonesia, \\ Email: ananta_budhi@stp-bandung.ac.id \\ ${ }^{2}$ Sekolah Tinggi Pariwisata Bandung, Jl. Dr. Setiabudhi No.186, Bandung Indonesia, \\ Email: haryadidarmawan@stp-bandung.ac.id \\ ${ }^{3}$ Sekolah Tinggi Pariwisata Bandung, JI. Dr. Setiabudhi No.186, Bandung Indonesia \\ Email: umk@stp-bandung.ac.id \\ * Corresponding Author
}

DOI: $\underline{10.47750 / Q A S / 22.184 .23}$

\begin{abstract}
This research examines the effect of digital innovation on the competitiveness and performance of hospitality businesses in Indonesia. This research was conducted with a quantitative research approach. Participants in this study are managers of hotel companies that implement online systems in Indonesia. The samples in this study were 218 respondents. Hypotheses are tested using the Structural Equation Modeling method and processed using Amos Software Version 23. The results show that there is a positive and significant effect between digital innovation on competitiveness, digital innovation and competitiveness also effect hotel business performance positively and significantly. We also found that competitiveness can mediate the effect of digital innovation on business performance. Therefore, we suggest improving business performance with enhancing competitiveness, to improve competitiveness can be done by increasing the implementation of digital innovation.
\end{abstract}

Keywords: Digital Innovation, Competitiveness, Business Performance, Hotel Industry

\section{Introduction}

The Coronavirus outbreak (Covid-19) in early 2020 has made many businesses tend to decline, including the hospitality sector. Therefore, the firm must optimize marketing including in digital innovation to stay successful in business. The hotel's occupancy decreased to 40 percent, impacting the business continuity of the hotel (Rahma \& Arvianti, 2020).

In this situation, the success of the hotel business at this time is largely determined by the ability to innovate, especially in innovation in digital marketing. Innovation is one of the keys to a company's success (Pranowo et al., 2020; Siregar et al., 2019 ; Siregar et al., 2021). Kenechi \& Purity, (2018) explained that digital innovation has become part of the production process, product pricing, and also marketing communication to enhance performance. Linking the opportunities of big data and the business transformation imperative resulting from digitization leads to a situation where incumbent firms must re-think and innovate in their business models and create new capabilities in order to gain competitiveness in their business ecosystem (Ylijoki et al., 2019). Innovation is one of the key factors for competitiveness. The higher the level of innovation of a company in running a business, the competitiveness will also be high (Osterle, Hubert, at.all 2001; Kuratko \& Howard Frederick, 2016).
Mattsson \& Ofrila-Sintes, (2014) cited that a model of innovation types for hotels has found strong support, and innovation in the hotel industry affects competitive advantage and performance.

Previous research about the relationship of innovation with competitiveness and business success has been conducted by Zaheer (2015), the finding showed that innovation was very important to improve businesses' competitiveness and business success. Innovativeness also will give the benefits to the business owner in the sustainability of their businesses to achieve business objectives efficiently and effectively, Zuliarni (2014), and competitiveness is the core for company performance (Tani et al., 2013). Gama et al., (2020) also said that the firms need a competitive advantage to survive in business.

Therefore, the research questions in this study are:

1. Does digital innovation effect the competitiveness of the hotel industry in Indonesia?

2. Does digital innovation can effect the business performance of the hotel industry in Indonesia

3. Does Competitiveness can effect the business performance of the hotel industry in Indonesia.

4. Does competitiveness can mediate the relationship between digital innovation on business performance. 


\section{Literature_Review}

\subsection{Digital Innovation}

Yfantidou et al., (2019) said that very important to introduce new service business models through continuous improvement of operating technology. Digital technology is more increasingly an important factor in achieving firms' goals, and its pervasive effects have resulted in the radical restructuring of entire industries (Nylén \& Holmström, 2015). Digital technology in particular has proven as a key to enhancing firm productivity and enhancing economic growth, bringing prosperity in many ways (Nylén \& Holmström, 2015).

Jose et al., (2015) cited that the results of the innovation can integrate the various components arising from the process of firm innovation, namely innovation of product, the innovation of process, organizational innovation, and innovation in marketing. Innovation creating new products, and processes and services (Radman \& Belin, 2017; Farida 2017). Farida ( 2017)

\subsection{Hotel Competitiveness}

The globalization and the increasing of technology and the emergence of ever more numerous competitors make the company must be able to compete (Madhok \& Marques, 2014). Competitiveness has become more important than ever for a firm's survival and success (Akben-Selcuk, 2016). Firm.competitiveness explains the ability of a firm to.compete with other companies. Competitiveness also can be explained as the level of productivity which is interpreted as the output produced by a workforce (Porter, 1990).

Another opinion said that firm competitiveness is defined as the ability of a firm to successfully compete in its environment (Tamayo et al., 2015). Competitiveness is defined as a nation's ability to command significant world market share in high technology products while maintaining the living standards of its citizens (Álvarez, Isabel, Raquel Marin, Fonfría, 2009). The most competitive organizations are in a better position to reach wider markets. Similarly, the firm's performance indicates that the firm has a high level of competitiveness, the more-profitable firms tend to be more competitive(Tamayo et al., 2015).

\subsection{Firm's Performance}

The company's ability to make a profit is called performance (Sar, 2017). The firm growth, financial gains by the firm, and customer orientation also related to business performance (Parida et al., 2009). Darroch, (2005) to measures, the firm performance uses the comparative and internally reflective that compare the growth of one firm to another firm. Grissemann et al., (2013) cited that performance of hotels refers to objective measures such as the average occupancy rate, and also market share. Performance is the level of achievement obtained by individual or group to achieve organizational goals (Siregar \& Lubis, 2017).

\subsection{Hypotheses and Research Model}

Digitalization implies technology-driven business changes. Thus, strategic management and IS research provide a broader view of the topic. Moreover, change requires innovation. Startups and incumbents search for new, technology, and datadriven innovations(Ylijoki et al., 2019). Firm competitiveness can be encouraged by fostering innovation in products and establishing the necessary conditions for increased cooperation with distributors and the development of more closely knit collaborative networks (Tamayo et al., 2015). To achieve competitiveness, it depends on the effectiveness of the company in doing innovation (Syamsuri et al., 2019).

Technology has become a crucial factor in increasing competitiveness and business performance (Radman \& Belin, 2017). Innovation is one of the crucial factors in achieving a sustainable competitive advantage (Veselica, 2019). The firm's ability to innovate is a very important factor to improve organizational performance (Ismanu, 2019), and also the growth and survives of an organization (Gaynor, 2002). Tani et al., (2013) in their study found that competitiveness improves business performance.

Based on the literature, we proposed the conceptual model below :

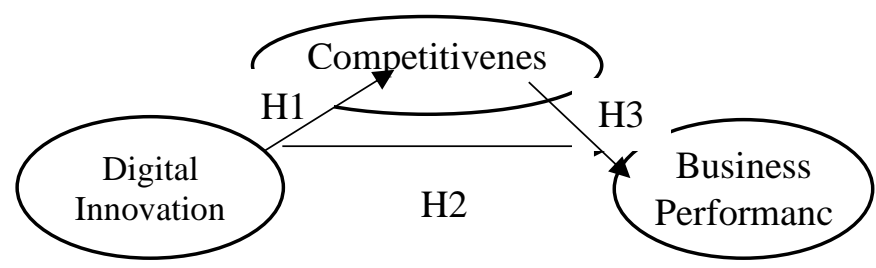

Figure 2: Conceptual Framework

\section{Research Methodology}

\subsection{Participants}

This research is quantitative. Participants in this study are managers of hotel companies that implement online systems in Indonesia. The sample in this study were 218 respondents. Hypotheses are tested using the Structural Equation Modeling method and processed using Amos Software Version 23.

\subsection{Measures}

There are three variables in this study, namely digital innovation, competitiveness, and performance. We use six statements to measure digital innovation, adopted from Paladino, (2007) using a five-point Likert-like scale ranging from $1=$ "strongly disagree" to $5=$ "strongly agree". Competitiveness using 4 questions adopted from (Man et al., 2002), (Chong, 2008), (Catherine L. Wang, 2004), (Zeng, S.X. \& Tam, 2010), (Peris-ortiz, 2017) using a five-point Likert-like scale ranging from 1 = "strongly disagree" to $5=$ "strongly agree". Performance is measured using 4 statement items adopted from the opinion (Darroch, 2005) using a five-point Likert-like scale ranging from $1=$ "strongly disagree" to $5=$ "strongly agree". 


\section{GENERAL MANAGEMENT}

\begin{tabular}{|c|c|c|}
\hline Variable & Indicator & $\mathrm{n}$ item \\
\hline $\begin{array}{l}\text { Digital } \\
\text { Innovation }\end{array}$ & $\begin{array}{l}\text { 1. The quality of our digital solutions is superior } \\
\text { compared to our competitor } \\
\text { 2. The features of our digital solutions are superior } \\
\text { compared to our competitors' } \\
\text { 3. The applications of our digital solutions are totally } \\
\text { different from our competitors' } \\
\text { 4. Our digital solutions are different from our } \\
\text { competitors' in terms of product platform } \\
\text { 5. Our new digital solutions are minor improvements of } \\
\text { existing products } \\
\text { 6. Some of our digital solutions are new to the market at } \\
\text { the time of launching }\end{array}$ & 6 \\
\hline Competitiveness & $\begin{array}{l}\text { 1. High of productivity } \\
\text { 2. The growth of sales } \\
\text { 3. Market share } \\
\text { 4. Response to opportunities and threats }\end{array}$ & 4 \\
\hline Performance & $\begin{array}{l}\text { 1. The firm growing more rapidly } \\
\text { 2. The firm performing better than } 5 \text { years ago } \\
\text { 3. The firm has met the objective } \\
\text { 4. The firm more profitable if compare with others }\end{array}$ & 4 \\
\hline
\end{tabular}

Source: Paladino, (2007), (Darroch, 2005), (Man et al., 2002), (Chong, 2008), (Catherine L. Wang, 2004), (Zeng, S.X. \& Tam, 2010), (Peris-ortiz, 2017)

Table 1: Construct and Measurements

\section{Finding}

\subsection{Normality Testing}

The result of normality testing is shown in Table 2 below:

\begin{tabular}{|l|l|l|l|l|}
\hline Variable & kew & c.r. & kurtosis & c.r. \\
\hline Perform4 & -.106 & -.637 & -.233 & -.702 \\
\hline Perform3 & -.007 & -.040 & -.367 & -1.106 \\
\hline Perform2 & -.157 & -.944 & -.574 & -1.728 \\
\hline Perform1 & .056 & .340 & -.500 & -1.506 \\
\hline Comp1 & -.101 & -.608 & -.486 & -1.465 \\
\hline Comp2 & -.052 & -.315 & -.222 & -.669 \\
\hline Comp3 & .223 & 1.345 & -.165 & -.499 \\
\hline Comp4 & .194 & 1.170 & -.774 & -2.334 \\
\hline Diglno1 & -.112 & -.673 & -.511 & -1.540 \\
\hline Diglno2 & .032 & .191 & -.593 & -1.788 \\
\hline Diglno3 & -.102 & -.612 & -.585 & -1.763 \\
\hline Diglno4 & .223 & 1.342 & -.552 & -1.662 \\
\hline Diglno5 & .073 & .439 & -.699 & -2.108 \\
\hline Diglno6 & .224 & 1.351 & -.502 & -1.512 \\
\hline Multivariate & & & 6.436 & 2.245 \\
\hline
\end{tabular}

Source: Data Processing

Table 2. Testing of Normality

The normality test is one of the most important assumptions in conducting structural equation modeling using Amos. The data used in this model must be normally distributed. In Structural Equation modeling, the skewness and kurtosis are the criteria to test the normality of the data. The skewness, kurtosis, and $\mathrm{cr}$ of multivariate value must be -2.58 to 2.58 (Schumacker
\& Lomax, 2010). Table 2 provides information that the internal data used in the study are normally distributed. Therefore there is no problem with the normality of the data and can proceed with the next steps. 


\section{GENERAL MANAGEMENT}

\subsection{Measurement_Model}

The measurement model aims to determine whether the indicators used are able to measure the variables. The recommended value of Composite Reliability $(\mathrm{CR})>0.70$, Average Variance Extracted (AVE) value $>0.50$, and Discriminant Validity (DV) not exceed the value of AVE (Hair at all, 2013).

\begin{tabular}{|c|c|c|c|c|c|}
\hline Variables & Item & Estimates & CR & AVE & DV \\
\hline \multirow[t]{6}{*}{$\begin{array}{l}\text { Digital } \\
\text { Innovation }\end{array}$} & $\begin{array}{l}\text { The quality of our digital solutions is superior compared to our } \\
\text { competitor }\end{array}$ & 0,728 & \multirow[t]{6}{*}{0.865} & \multirow[t]{6}{*}{0.517} & \multirow[t]{6}{*}{0.361} \\
\hline & $\begin{array}{l}\text { The features of our digital solutions are superior compared to } \\
\text { our competitors' }\end{array}$ & 0,729 & & & \\
\hline & $\begin{array}{l}\text { The applications of our digital solutions are totally different } \\
\text { from our competitors' }\end{array}$ & 0,762 & & & \\
\hline & $\begin{array}{l}\text { Our digital solutions are different from our competitors' in } \\
\text { terms of product platform }\end{array}$ & 0,749 & & & \\
\hline & $\begin{array}{l}\text { Our new digital solutions are minor improvements of existing } \\
\text { products }\end{array}$ & 0,651 & & & \\
\hline & $\begin{array}{l}\text { Some of our digital solutions are new to the market at the time } \\
\text { of launching }\end{array}$ & 0,691 & & & \\
\hline \multirow[t]{4}{*}{ Competitiveness } & Our business hotel has high productivity compared to others & 0,779 & \multirow[t]{4}{*}{0.854} & \multirow[t]{4}{*}{0.595} & \multirow[t]{4}{*}{0.389} \\
\hline & $\begin{array}{l}\text { Our hotel room occupancy rate is higher compare to } \\
\text { competitors }\end{array}$ & 0,819 & & & \\
\hline & We have a high market share & 0,793 & & & \\
\hline & We can response to opportunities and threats & 0,687 & & & \\
\hline \multirow{4}{*}{$\begin{array}{l}\text { Business Hotel } \\
\text { Performance }\end{array}$} & Our business hotel are growing more rapidly than others & 0,774 & \multirow[t]{4}{*}{0.863} & \multirow[t]{4}{*}{0.612} & \multirow[t]{4}{*}{0.251} \\
\hline & $\begin{array}{l}\text { In general, our firm is performing better than it did five years } \\
\text { ago }\end{array}$ & 0,783 & & & \\
\hline & $\begin{array}{l}\text { Over the past } 12 \text { months, our firm has met its performance } \\
\text { objective }\end{array}$ & 0,762 & & & \\
\hline & Compared with the industry average, we are more profitable & 0,810 & & & \\
\hline
\end{tabular}

Table 3: The Measurement Model

The measurement model result shows that the value is on the recommended value. The Construct Reliability (CR) value > 0.70, The Variance Extracted (AVE) value $>0.5$, and Discriminant Validity Value not exceed the value of Variance Extracted (AVE) value. Therefore, the instruments in this model are valid and reliable.

\subsection{The Goodness_of Fit Test}

The criteria to see the goodness of fit model are the value of Adjusted GFI (AGFI) > 0.90, the value of Goodness_of Fit Index $(\mathrm{GFI})>0.90$, the value of $\mathrm{CFI}>0.90$, TLI value $>0.90$, RMSEA $<0.08$, and RMR value $<0.05$ (Hair et al, 2017), (Schumacker \& Lomax, 2010).

\begin{tabular}{|l|l|l|}
\hline The Goodness_of Fit_Index & Result & Decision \\
\hline Cmin/DF & 1.922 & Good Fit \\
\hline Adjusted Goodness of Fit (AGFI) & 0.870 & Marginal Fit \\
\hline The goodness_of_Fit Index (GFI) & 0.908 & Good Fit \\
\hline Comparative_Fit_Index (CFI) & 0.954 & Good Fit \\
\hline Tucker Lewis_Index (TLI) Error of & 0.943 & Good Fit \\
\hline $\begin{array}{l}\text { Root Mean Square Eroximation (RMSEA) } \\
\text { Approximal (RMSR) }\end{array}$ & 0.065 & Good Fit \\
\hline Root Mean Square Residual & 0.043 & Good Fit \\
\hline
\end{tabular}

Table 4: The Goodness of Fit Test of the Model

Table 4 shows that the model in this study is in the fit model category. It can be seen from the value Adjusted Goodness of Fit (AGFI) in marginal fit criteria with a value of 0.870 . The Goodness of Fit Index (GFI) is $0.908>0.900$ Comparative Fit Index (CFI) has a value of $0.954>0.900$. Tucker-Lewis Index (TLI) has a value of $0.943>0.900$. The Root Mean Square Error of_Approximation (RMSEA) has a value of $0.065<0.080$ and Root Mean Square.Residual (RMSR) has a value of $0.043<$ 0.05 . Although Adjusted Goodness of Fit (AGFI) in the marginal fit category, this model is still said to be fit because it is already represented by other criteria (Hair at all, 2013).

\subsection{Hypotheses Testing}

The test statistic to test hypotheses is the critical ratio (C.R.) and probability value (Byrne, 2010). The critical ratio needs to be $>1.96$ and a probability level of .05 (Byrne, 2010). 


\section{GENERAL MANAGEMENT}

\begin{tabular}{|l|l|l|l|}
\hline Relation & Estimate & $\mathbf{R}$ & $\mathbf{P}$ \\
\hline Digital Innovation on Competitiveness & 0.601 & 6.852 & .000 \\
\hline $\begin{array}{l}\text { Digital Innovation on Business Hotel } \\
\text { Performance }\end{array}$ & 0.197 & 2.196 & .028 \\
\hline $\begin{array}{l}\text { Competitiveness on Business Hotel } \\
\text { Performance }\end{array}$ & 0.505 & 5.256 & .000 \\
\hline
\end{tabular}

Table 5: Hypothesis Testing Result

Table 5 shows that all forms of relationships between digital innovation on competitiveness, digital innovation, and competitiveness on business hotel performance have a critical ratio $>1.96$ and probability value $<0.05$. It means that all hypotheses are accepted.

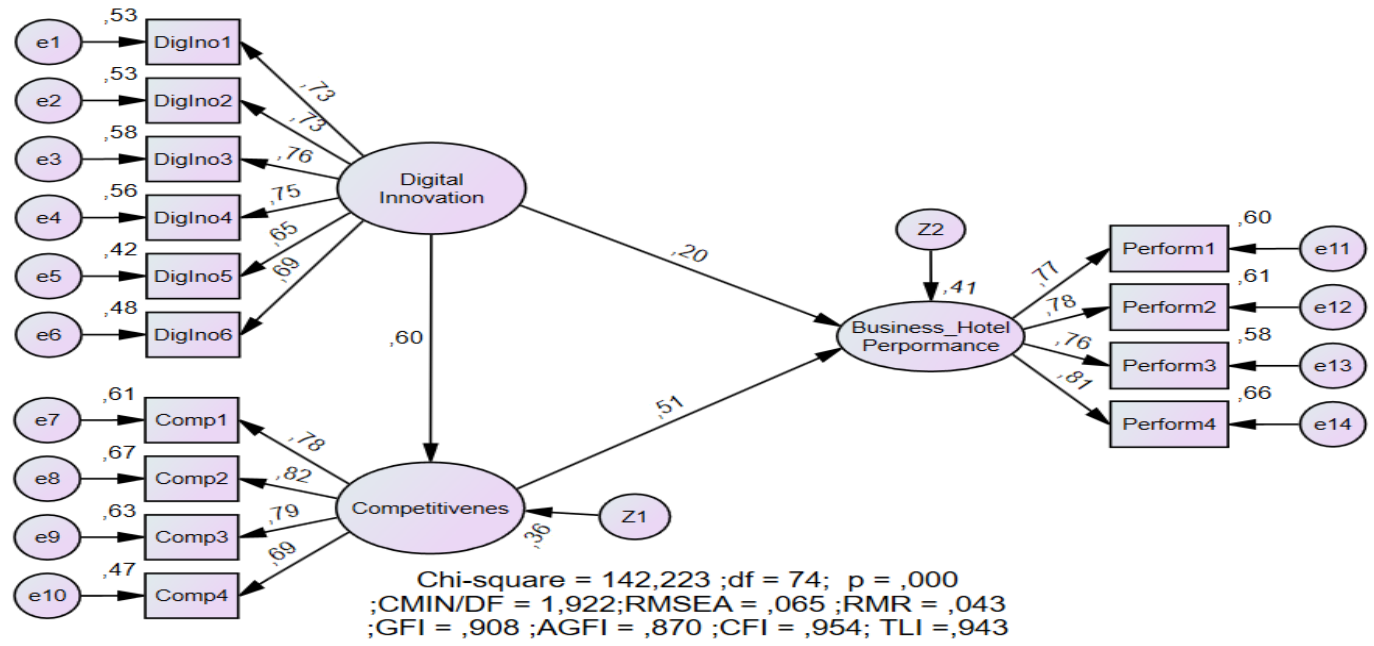

Figure 4: The Full Model of Research

\subsection{Discussion}

This study examines the effect of digital innovation and competitiveness on the performance of hospitality businesses in Indonesia. Technology has become a very important factor in increasing competitiveness and business performance (Radman \& Belin, 2017) and organization needs to be more innovative to enhance business success (Siregar et al., 2019b). For the first hypothesis, a loading factor of 0.601 is obtained with a Critical Ratio (CR) of 6,852> 1,967 and a probability of $0,000<0.05$ Therefore, it means that digital innovation affects the competitiveness of the hospitality business in Indonesia. In other term, digital innovation is very important to increase business competitiveness.

Nadia et al. (2016) in their study also discussed innovation and competitive advantage in Malaysia. They found that innovation effect competitive advantage in the food industry SMEs in Malaysia. Therefore, companies must continue to innovate to improve business competitiveness.

Hypothesis two testing results obtained a loading factor of 0.197 with a Critical Ratio (CR) of 2,196> 1,967 and a probability of $0.028<0.05$ Therefore, it means that digital innovation influences the performance of the hospitality business in Indonesia. This shows that increasing digital innovation will improve business performance. This is relevant to Zaheer (2015) that said that innovation was an important factor in supporting the businesses' competitiveness and success. Grissemann et al., (2013) also said that innovation has been widely recognized as key factor in enhancing the business performance of hotels.

Hypothesis testing related to competitiveness on performance shows that the hypothesis is accepted. This means that there is a positive and significant effect of competitiveness on performance. This can be seen from the loading factor value of 0.505 with a critical ratio of 5.256 and a probability of 0.000 . The research study conducted by Tani et al., (2013) also found that competitiveness has a very important role in improving business performance.

The results of direct and indirect effects show that the direct effect between digital innovation on the performance of the hotel business in Indonesia is 0.197 or $19.7 \%$. The indirect effect of digital innovation through competitiveness on hotel business performance is 0.304 or $30.4 \%$. This shows that the influence does not have the greatest effect on business performance compared to the direct effect of digital innovation on business performance. In other words, competitiveness has a role as a mediator in this research that can link the influence of digital innovation on the performance of the hospitality business in Indonesia.

\section{Conclusion}

The hypothesis proposed in this study proved to be accepted. Digital innovation affects competitiveness positively and significantly, digital innovation and competitiveness have a positive and significant effect on the performance of the hospitality business in Indonesia. We also find that power has a role as an intervening variable that is able to mediate the relationship between digital innovation on performance. We recommend that digital innovation be further enhanced because this will have an impact on improving the competitiveness and performance of the hospitality business. 


\section{References}

[1] Akben-Selcuk, E. (2016). Factors Affecting Firm Competitiveness: Evidence from an Emerging Market. International Journal of Financial Studies, 4(2), 9 https://doi.org/10.3390/ijfs4020009

[2] Álvarez, I., Marin, R., \& Fonfría, A. (2009). The role of networking in the competitiveness of firms. Technological Forecasting and Social Change, 76(3), 410-421. doi:10.1016/j.techfore.2008.10.002

[3] Brown, G. (2006). Mapping Landscape Values and. Tourism, 113(November 2012), 101-113. https://doi.org/10.1002/jtr

[4] Byrne, B. M. (2010). Structural Equation Modeling with AMOS. In Structural Equation Modeling with Amos Basic Concepts, Applications, and Programming (2nd ed.). Taylor \& Francis Group. doi: 10.4324/9781410600219

[5] Catherine L. Wang, P. K. A. (2004). The development and validation of the organisational innovativeness construct using confirmatory factor analysis. European Journal of Innovation Management Volume 7 Number 42004 Pp. 303-313, 7(4), 303313. https://doi.org/10.1016/j.technovation.2009.08.003

[6] Chong, H. G. (2008). Measuring performance of small-andmedium sized enterprises: the grounded theory approach. Journalof Business and Public Affairs, 2(1), 1-11.

[7] Darroch, J. (2005). Knowledge management, innovation and firm performance. Journal of Knowledge Management, 9(3), 101115. doi:10.1108/13673270510602809

[8] Farida, N. (2017). Antecedent of Innovation and Marketing Performance in Batik Industry. Advanced Science Letters, 23(1), 471-474. doi:10.1166/asl.2017.7226

[9] Gama, A. W. S., Wiagustini, N. L. P., Sedana, I. B. P. S., \& Purbawangsa, I. B. A. (2020). Intellectual Capital and Financial Performance of Indonesian Banks. Quality - Access to Success, 21(177), 9-14.

[10] Gaynor, G. H. (2002). Innovation by Design: What It Takes to Keep Your Company on the Cutting Edge. Amacom.

[11] Grissemann, U., Plank, A., \& Brunner-Sperdin, A. (2013). Enhancing business performance of hotels: The role of innovation and customer orientation. International Journal of Hospitality Management, 33, 347-356 doi:10.1016/j.ijhm.2012.10.005

[12] Hair, J. F. H., Hult, G. T., Ringle, C. M., \& Sarstedt. (2017). A Primer on Partial Least Squares Structural Equation Modelling (PLS-SEM). Sage Publications.

[13] Ismanu, S. (2019). Innovation and Firm Performance of Small and Medium Enterprises. Review of Integrative Business and Economics Research, 8(2), 312-323.

[14] Jose, M., Silva, M., Simões, J., Sousa, G., Moreira, J., \& Mainardes, E. W. (2015). Empirical evidence from services firms. Innovation: Management, Policy \& Practice, 16(3), 404-416. https://doi.org/10.1080/14479338.2014.11081996

[15] Kenechi, J., \& Purity, O. (2018). Digital Innovation: Competitive Strategy for College Startups in Nigerian Campuses. International Journal of Academic Research in Business and Social Sciences, 8(11), 1007-1021. https://doi.org/10.6007/IJARBSS/v8-i11/4980

[16] Kuratko, D. F., \& Howard Frederick, A. O. (2016). Entrepreneurship, Theory/Process/Practice, 4th Edition, Cencage Learning, Australia.

[17] Madhok, A., \& Marques, R. (2014). Towards an action-based perspective on firm competitiveness. BRQ Business Research Quarterly, 17(2), 77-81. doi:10.1016/j.brq.2014.03.002

[18] Man, T. W. ., Lau, T., \& Chan, K. . (2002). The competitiveness of small and medium enterprises. Journal of Business Venturing, 17(2), 123-142. doi:10.1016/s0883-9026(00)00058-6

[19] Aziz, N. N. A., \& Samad, S. (2016). Innovation and Competitive Advantage: Moderating Effects of Firm Age in Foods Manufacturing SMEs in Malaysia. Procedia Economics and Finance, 35, 256-266. doi:10.1016/s2212-5671(16)00032-0
[20] Nylén, D., \& Holmström, J. (2015). Digital innovation strategy: A framework for diagnosing and improving digital product and service innovation. Business Horizons, 58(1), 57-67. doi:10.1016/j.bushor.2014.09.001

[21] Paladino, A. (2007). Investigating the Drivers of Innovation and New Product Success: A Comparison of Strategic Orientations. Journal of Product Innovation Management, 24(6), 534-553. doi:10.1111/j.1540-5885.2007.00270.x

[22] Parida, V., Pemartin, M., \& Frishammar, J. (2009). The impact of networking practices on small firm innovativeness and performance: a multivariate approach. International Journal of Technoentrepreneurship, 2(2),

115 doi:10.1504/ijte.2009.031500

[23] Peris-Ortiz, M., \& Ferreira, J. J. (Eds.). (2017). Cooperative and Networking Strategies in Small Business. Innovation, Technology, and Knowledge Management. doi:10.1007/978-3319-44509-0

[24] Porter, M. E. (1990). "Competitive Strategy"., Techniques for Analysing Industries and Competitors. The Free Press.

[25] Radman, G., \& Belin, A. (2017). How to Keep On? International Journal of Digital Technology \& Economy, 2(1), 45-56.

[26] Rahma, V. S., \& Arvianti, G. F. (2020). The impacts of covid-19 pandemic in indonesia and china's hotel industry: how to overcome it? Jelajah: Journal Tourism and Hospitality, 2(1), 5564.

[27] Sar, A. K. (2017). Competitive advantage and performance: an analysis of Indian Downstream Oil and Gas Industry. Academy of Accounting and Financial Studies Journal, 21(2), 1-7.

[28] Schumacker, R. E., \& Lomax, R. G. (2010). A Beginner's Guide to Structural Equation Modeling (3rd ed.). Taylor \& Franciss Group.

[29] Siregar, Z. M. E., \& Lubis, J. (2017). Merit System in The Placement of Civil Servants and its Effect toward Performance of Sub-district Office in Labuhanbatu Region Nort Sumatera. IOP Conference Series: Materials Science and Engineering PAPER, 180. https://doi.org/10.1088/1742-6596/755/1/011001

[30] Siregar, Z. M. E., Sujana, F. R., Pranowo, A. S., \& Supriadi, Y. N. (2021). Job autonomy and innovative work behavior of marketing employees in the automotive industry in Indonesia: The mediating role of organizational commitment. Quality Access to Success, 22(180), 97-102.

[31] Siregar, Z. M. E., Suryana, Ahman, E., \& Senen, S. H. (2019a). Does knowledge management enhance innovation: A literature review. International Journal of Scientific and Technology Research, 8(9), 1991-1994. http://www.ijstr.org/finalprint/sep2019/Does-Knowledge-Management-EnhanceInnovation-A-Literature-Review.pdf

[32] Siregar, Z. M. E., Suryana, Ahman, E., \& Senen, S. H. (2019b). Factors influencing innovative work behavior: An individual factors perspective. International Journal of Scientific and Technology Research, 8(9), 324-327.

[33] Syamsuri, A. R., Musannip, Z., \& Siregar, E. (2019). Organizational Transformation Strategy: Perspective Of HRM Theory. International Journal of Scientific \& Technology Research, 8(10), 2251-2256.

[34] Tamayo, J. A., Romero, J. E., Gamero, J., \& Martínez-Román, J. A. (2015). Do Innovation and Cooperation Influence SMEs Competitiveness? Evidence From the Andalusian MetalMechanic Sector. Innovar, 25(55), 101-115. doi:10.15446/innovar.v25n55.47226

[35] Tani, L. H., Zain, D., Wirjodirjo, B., \& Djumahir, D. (2013). The Role of Competitiveness as Mediator for the Relation between Supply Chain Flexibility and Firm Performance. Journal of Management Research, 5(1). doi:10.5296/jmr.v5i1.2904

[36] Veselica, R. (2019). The Impact of Digital Innovation on National Competitiveness. 38th International Scientific Conference on Economic and Social Development, March, 441-448.

[37] Yfantidou, G., Spyridopoulou, E., Chatzigeorgiou, T., \& Malliou, P. (2019). Hotel Innovation and the Creation of Competitive Advantage. Springer Proceedings in Business and Economics, 


\section{GENERAL MANAGEMENT}

135-144. doi:10.1007/978-3-030-03910-3 10

[38] Ylijoki, O., Sirkiä, J., Porras, J., \& Harmaakorpi, V. (2019). Innovation capabilities as a mediator between big data and business model. Journal of Enterprise Transformation, 1-18. doi:10.1080/19488289.2018.1548396

[39] Zaheer, H. (2015). How Do Innovative Digital Start-Ups Achieve Success? Perspectives of Australian Founders (Issue October). https://www.researchonline.mq.edu.au/vital/access/services/Do wnload/mq:47062/SOURCE1?view=true
[40] Zeng, S. X., Xie, X. M., \& Tam, C. M. (2010). Relationship between cooperation networks and innovation performance of SMEs. Technovation, 30(3), 181-194. doi:10.1016/j.technovation.2009.08.003

[41] Zuliarni, S. (2014). Industri Kreatif Sub Sektor Kerajinan Di. Jurnal Aplikasi Bisnis, 4(2), 110-123. 